\title{
Land Use Changes and Volumetric Processes in the Tinto Salt-marshes
}

\author{
Ramírez-Juidías Emilio ; Tejero-Manzanares José ; Moreno-Fresno Juan José ${ }^{1}$; Justicia-Segovia Meritxell ${ }^{1}$; \\ Madueño-Luna Antonio ${ }^{1}$; López-Lineros Miriam ${ }^{3}$ \\ ${ }^{1}$ ETSIA, University of Seville, Seville, 41013, Spain \\ ${ }^{2}$ EUP, University of Castilla La Mancha, Almadén, 13071, Spain \\ ${ }^{3}$ EPS, University of Seville, Seville, 41011, Spain
}

\begin{abstract}
The Tinto Marshes is a natural area located at the mouth of the Tinto's river (Huelva, Spain), being, in size, the third largest wetland in the province of Huelva after Doñana and Odiel salt-marshes. Due to its special topography, as they are characterized as salt-marshes, their characterization, both altimetric and volumetric, is quite complex. In this research, Landsat TM and ETM satellite images from the United States Geological Service (USGS) were analyzed for a period of $\mathbf{3 5}$ years, which were examined and classified in a certain period of time in order to characterize the dynamic changes (floods and land use changes) in the Tinto Tidal Marshes. The erosion phenomena were studied and analyzed through the use of different DEM and UAV data. All data were integrated into a GIS. Results shown how the forest fires and the oak decline of Quercus are the two processes that accelerate the conversion of forest stands in scrub areas or pastureland. Moreover, the ecological preservation of the Tinto salt-marshes results in a similarity of the volumetric change processes produced in the study periods. Erosion processes are an immediate consequence of the low kinetic energy in the Tinto river and hence of the progressive increase of the negative rate of eroded soil.
\end{abstract}

Keywords-historic flood; biodiversity; tinto salt-marshes; GIS; remote sensing.

\section{INTRODUCTION}

The existence of a coastal salt-marsh depends essentially on the balance between sedimentation and erosion [1]. However their complex structure and zonation usually represent a fluctuating equilibrium with the intertidal environment.

According to [2], wetlands are ecosystems that tend to disappear in an evolutionary process of silting. Nonetheless human activity has caused hitherto the acceleration of this process as well as other also negative, so that it has lost much of its original area [3].

At present, the effects of recent climate change on wetlands are masked by the more recent impact of our activity, giving rise to a landscape transformation and causing an important land use change (LUC). Moreover, the marsh flatness has always been subjected to a variable flooding regime according to rainfall, the flow rates supplied by water avenues and the tidal regime. Flooding processes in marshes spaces are substantially controlled by their altimetric characteristics, in addition to the effect of subsidence processes and/or upper-level, which are often insufficiently reflected in conventional contour lines mapping [4]. A possible solution to this problem would be use remote sensing images to very low level obtained with unmanned aerial vehicle (UAV) [5], although always with the help of ground work.

For this reason, the aim of this paper will be, on one hand, obtain images of different areas in Tinto salt-marshes with UAV to study the problem of erosion a small-scale, and the other hand, use satellite imagery and Geographic Information Systems (GIS) to calculate the different levels in Tinto salt-marshes, predict the volumetric change processes from climatic data, and characterize the LUC at macro-scale level.

The paper is organized as follows. In the next section, both the study area and data and methodology are presented. Section 3, presents all obtained results via computational simulation and its discussion. Finally, we conclude our paper in section 4.

\section{MATERIALS AND METHOD}

\section{A. Study area}

The Tinto salt-marshes, with a total area of $32867946.31 \mathrm{~m}^{2}$, are located in the province of Huelva (Southwest of the Iberian Peninsula), associated to Tinto river mouth. These salt-marshes are located to $3.5 \mathrm{~km}$ of the Odiel salt-marshes.

According to [4], the area is integrated in a complex system of estuaries of recent sedimentation influenced, in their genesis, by level changes of Earth's crust [6]. In the marshes are given simultaneously both sedimentation and erosion processes that vary in space and time, creating a lot of temporary or permanent physiographic characteristics giving rise to a considerable variety of habitats. The tidal movement is the main determining factor in shaping of these ecosystems.

The area consists of a tidal marsh area well preserved and another area, Dehesa de Alquería, where both forest and dry-land crops are predominant.

In another vein, the climate in the study area can be defined as mediterranean maritime, with an insolation grade exceeding $3000 \mathrm{~h} /$ year. In the winter season, short and smooth, are produced most of the rains. By the other hand, the summers are dry and long though smoothed out by the proximity of the ocean, not exceeding, usually, the absolute 
maximum temperature of $44{ }^{\circ} \mathrm{C}$. The average annual rainfall is $483.922 \mathrm{~mm}$, being concentrated in the months of December and January, presenting, likewise, a dry season with deficient water balance between the months from May to September [4].

\section{B. Data and methodology}

In this study, 30 orthorectified Landsat satellite images available from the United States Geological Service (USGS) Earth Explorer archive were obtained for the 1975 to 2010 period. Each satellite image was examined and classified in a determined period of time in order to characterize the dynamic changes in the Tinto Marshes. All images (Path 218 Row 34 "WRS-1" and Path 202 Row 34 "WRS-2") were acquired during the month of July 2013. Postclassification processing was necessary in order to avoid to certain details were classified as water. Tinto marsh surfaces extent was calculated in Ilwis GIS.

Each satellite image was enhanced, and then using the nearest neighbor algorithm, achieving to maintain unchanged the original brightness of the pixel values according to [7].

To calculate the different levels in Tinto salt-marshes, predict the volumetric change processes from climatic data, and characterize the LUC at macro-scale level, were used the method described by [4].

At micro-scale level, was necessary to establish a total of 23 control points distributed by the study area (Fig. 1), all of them identified by georeferenced photogrammetric images for the period 1973 to 2010 obtained of Iberpix (National Geographic Institute of Spain). Likewise, during the month of September 2013, were acquired images of the study area via an UAV, which were georeferenced in the European Terrestrial Reference System 1989.

To obtain a good analysis of the study area was necessary establishing two new period of time into the initial established period (1973-1985 and 1985-2010), which were compared with the data collected in situ via UAV in September 2013 to be able to obtain the total volume of erosioned soil in Tinto salt-marshes.

For each period all images, including the UAV images, were orthorectified with a 25 (first period 1973-1985), 10 (second period 1985-2010) and 5 (UAV data) m resolution DEM belonging to Andalusian Government (second period) and the National Geographic Institute of Spain (all other periods). These DEM's provide suitable resolution to obtain the different levels of Tinto salt-marshes with the help of the control points selected within the study area [8] and iterative processes.

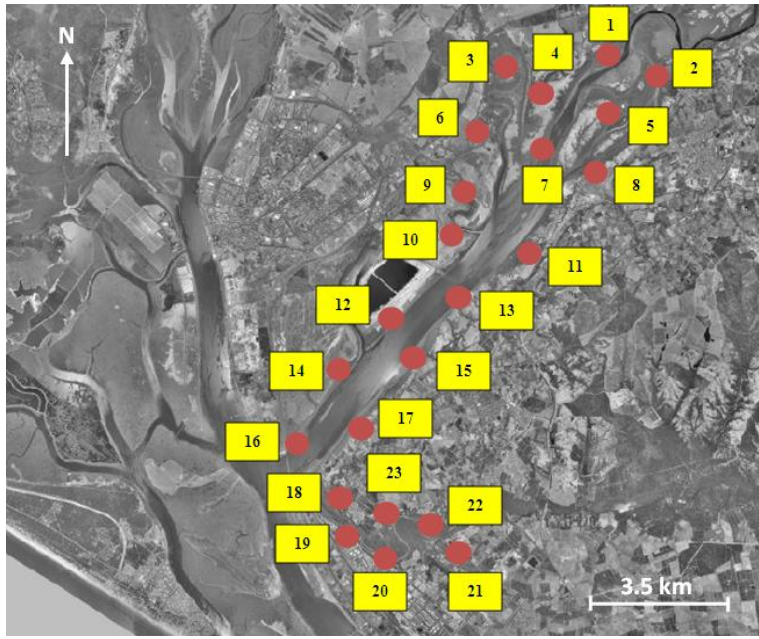

Figure 1. Distribution of control points in the study area

Also through iterative processes were obtained, in each pixel of both satellite and UAV images, the average depth water of Tinto salt-marshes in each period, which was necessary to obtain the erosioned soil in these salt-marshes.

According to [4], in another vein was carried out a deep literature review aimed to determine the possible existence of a temporal record of precipitation in the Tinto saltmarshes broad enough to obtain results, discussions and conclusions coherent with the present study.

\section{RESULTS AND DISCUSSION}

\section{A. Land use changes}

Regarding altered or constructed areas for the period from 1956 to 2007 [9], can be appreciated a significant increase of these areas $\left(6544 \cdot 10^{4} \mathrm{~m}^{2}\right.$ in $1960 \mathrm{~s}, 16237 \cdot 10^{4} \mathrm{~m}^{2}$ in $1990 \mathrm{~s}$ and $22323 \cdot 10^{4} \mathrm{~m}^{2}$ in $2000 \mathrm{~s}$ ) due to the expansion of the urban fabric and the construction of new housing estates, mainly on the coast [9], where the built-up area has increased six-fold owing to tourism development, intensive agriculture and rising industrialized areas.

In another vein, wetlands and water surfaces had a slight increase of $2564 \cdot 10^{4} \mathrm{~m}^{2}$ between 1956 and 2007, registering the major changes in littoral wetlands, being the total area $9 \%$ lower than to its original extent $\left(33 \cdot 10^{7} \mathrm{~m}^{2}\right.$ in 1956).

The land use changes of forestry and natural areas have particular importance given the size of these spaces in the province of Huelva $\left(778921 \cdot 10^{4} \mathrm{~m}^{2}\right.$ in $1960 \mathrm{~s}, 784322 \cdot 10^{4}$ $\mathrm{m}^{2}$ in $1990 \mathrm{~s}$ and $763533 \cdot 10^{4} \mathrm{~m}^{2}$ in $2000 \mathrm{~s}$ due to their conversion in agricultural areas).

According to [9], the reforestations (mostly eucalyptus) carried out explain the evolution followed by wooded forest area in the study area, as well as the loss of a third of the $306126 \cdot 10^{4} \mathrm{~m}^{2}$ occupied in 1956 by treeless scrub formations.

Finally, it is important to mention the two processes that accelerate the conversion of forest stands in scrub areas or pastureland and therefore the change of typology within the land use changes of forestry and natural areas, i.e., forest 
fires (nearly $7889 \cdot 10^{4} \mathrm{~m}^{2}$ between 1999 and 2007) and the oak decline of Quercus (this disease causes the death of both holms and cork oaks and reduces the economic profitability of the dehesa) [9].

\section{B. Prediction of the volumetric change processes}

After analyzing the meteorological data, it was obtained an equation, sufficiently significant $(\leq 0.001)$, to predict the precipitation in Tinto as from the rainfall Doñana. The equation is:

$$
\begin{aligned}
& y=354.936+0.857 \times P-0.165 \times A \\
& r=0.97 \\
& R^{2}=0.94
\end{aligned}
$$

Where " $y$ " is the prediction of rainfall in the Tinto saltmarshes in $\mathrm{mm}$, "P" is the rainfall data in Doñana saltmarshes in $\mathrm{mm}$ and " $\mathrm{A}$ " is the year.

According to [4], and after analyzing satellite images, a progressive decrease in annual water surface was obtained in Tinto salt-marshes.

The Tinto salt-marshes area analysis showed that the 1960 s had the most water surface that 1990s and 2000s, with no significant differences between 1990s and 2000s. The $32867946.31 \mathrm{~m}^{2}$ of Tinto salt-marshes, corresponding to the maximum area flooded, are equivalent to a maximum volume of $48.35 \cdot 10^{6} \mathrm{~m}^{3}$ after performing the prediction.

After to extrapolate data from satellite images to GIS, was estimated the depth of study area after carrying out a joint analysis with the different DEM's used. Likewise, and for each period and UAV data, were observed significant relationships (Table 1) between the volume of water and the Tinto salt-marshes surface. Fig. 2 shows estimated volume and area in Tinto salt-marshes for each period, both estimated through iterative processes using a total of five hundred random sample points selected in the satellite images, and very important to be able to obtain the erosioned soil in these salt-marshes.

Also, one-way analysis of variance for correlated samples [10] was carried out to estimate differences in depth, as well very important to predict the eroded soil, in each period, whose result is shown in Table 2 .

Likewise and in order to check the differences between periods, was carried out a Tukey HSD test, where it was obtained a significant difference $(\mathrm{p} \leq 0.01)$ between period 1 (1973-1985) and 2 (1985-2010), and between period 2 and 3 (UAV data), a result expectable as a consequence of the different DEM used.
TABLE I. PREDICTION OF VOLUME IN EACH PERIOD ACCORDING TO THE DEM USED ("Y" Is THE PREDICTION OF VOLUME IN THE TINTO SALTMARSHES IN HM ${ }^{3}$ AND "S" Is THE ESTIMATED SURFACE IN THESE SALTMARSHES IN KMㄹ)

\begin{tabular}{llll}
\hline Period & $\begin{array}{l}\text { DEM } \\
\text { used }\end{array}$ & Equation & Significance \\
\hline $1973-$ & $25 \mathrm{~m}$ & $y=-8.615+1.633 \times S$ & $\leq 0.001$ \\
1985 & & $r=0.98$ & \\
& & $R^{2}=0.91$ \\
$1985-$ & $10 \mathrm{~m}$ & $y=-8.227+1.613 \times S$ & $\leq 0.001$ \\
2010 & & $r=0.98$ \\
& & $R^{2}=0.91$ \\
UAV & $5 \mathrm{~m}$ & $y=-8.627+1.635 \times S$ & $\leq 0.001$ \\
data & & $r=0.98$ & \\
& & $R^{2}=0.92$ & \\
& & & \\
& &
\end{tabular}

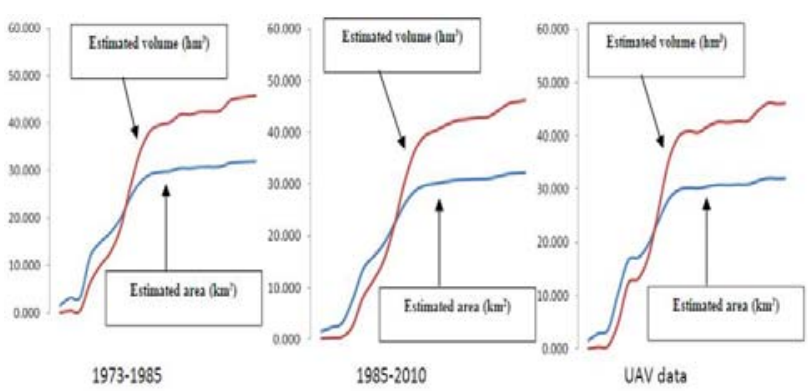

Figure 2. Estimated volume $\left(\mathrm{hm}^{3}\right)$ and area $\left(\mathrm{km}^{2}\right)$ in each period by random sample points

TABLE II. ANOVA SUMMARY FOR ESTIMATED DEPTH

\begin{tabular}{llllll}
\hline & SS & df & MS & F & P \\
\hline $\begin{array}{l}\text { Treatment (between } \\
\text { groups) }\end{array}$ & 0.0775 & 2 & 0.0387 & 10.47 & 0.000191 \\
Error & 0.1647 & 44 & 0.0037 & & \\
Blocks (periods) & 74.4531 & 22 & & & \\
Total & 74.6953 & 68 & & & \\
\hline
\end{tabular}

However, the interaction between period 1 and 3 is nonsignificant, probably because the UAV flew at a height such (50 $\mathrm{m}$ above ground) that has been able to capture the density of marsh vegetation in full, giving as a result a random resemblance to the model obtained in the first period. This in turn is related to the middle of the second period, due to the establishment in the area of the figure of natural landscape, doing of the ecological preservation of place a strong point in order to maintain the marsh, reason that in 2013 the model is very similar to the first period (in this period the low density of buildings and population in areas close to Tinto salt-marshes gave rise to its almost complete ecological maintenance).

\section{Prediction of the erosion in Tinto salt-marshes}

Sediment transport was obtained between consecutive periods and by pixel in Tinto salt-marshes by difference of 
the different DEM used. After, a multiple linear regression was applied to all data obtained to be able to predict the total volume of eroded soil (5) in the study period.

$$
\begin{aligned}
& y=0.008-0.563 \times S D+2.903 \times T \\
& r=0.937 \\
& R^{2}=0.867
\end{aligned}
$$

Where " $y$ " is the prediction of total volume of eroded soil in the Tinto salt-marshes in $\mathrm{hm}^{3}$, "SD" is the equivalent area, in $\mathrm{km}^{2}$, in which has occurred the volume of eroded soil, and which has caused an increase or decrease in the level " $T$ " of the bed of Tinto salt-marshes in $\mathrm{m}$.

Erosion dynamic divides Tinto salt-marshes into two zones. The Southern zone presents the highest erosion rates due to tidal effects to a greater extent, with a mean value of total erosion of $0.19 \mathrm{~m}$. Also, the higher levels of anthropogenic pressures might contribute to increase the erosion [11]. However, in the Northern area, with a mean value of total erosion of $0.11 \mathrm{~m}$, and with the existence of the Tartessos' Industrial Park, the dumping of raw sewage and solid waste increase the vulnerability of the area and it can mask the real value of total erosion.

The erosion in the Tinto salt-marshes has caused, in the total of study period, a loss of $3580000 \mathrm{~m}^{2}$ of equivalent area giving rise to a total volume of eroded soil of $1136640 \mathrm{~m}^{3}$. According to [11], this erosion hinders the development of marshes by successional processes.

\section{CONCLUSION}

As in the Odiel salt-marshes, and according to [4], the Tinto salt-marshes experience an annual filling process coinciding with the months of highest rainfall, and a water loss concentrated in the summer months. In this regard, the use of different DEMs gave rise to the prediction of volumes with significant differences between period 1 $(1973-1985)$ and $2(1985-2010)(p \leq 0.05)$, and between period 2 and 3 (UAV data) $(\mathrm{p} \leq 0.01)$, being one of the main factors of these significant differences the ecological preservation of the study area in the middle of the second period. This is related to the gradual increase in temperature in recent years, and with the gradual decrease of rainfall (dry period), which together with the slow accumulation of sediments favors the loss of equivalent area in the total of the study period.

In turn, the LUC produced in Tinto salt-marshes is related to loss of wetlands and littoral water areas, not only because of the two processes that accelerate the conversion of forest stands in scrub areas or pastureland and therefore the change of typology within the land use changes of forestry and natural areas, i.e., forest fires and the oak decline of Quercus, but also to the progressive increase of the negative rate of eroded soil (sediment deposition) that might also reflect lower wave energy, and therefore a possible rise in sea level, resulting in a decrease in the kinetic energy in the Tinto river [11].

Finally, and in keeping with the results obtained, it is necessary to emphasize the importance of using UAV's to study phenomena related to the environment, and its suitability in the study and evolution of LUC.

\section{REFERENCES}

[1] Davy A.J., Responses of salt marshes to change. Available: http://www-eawag-icef.emp-eaw.ch/abstracts/davy.pdf . Accessed on [2013-06-09].

[2] Pérez-Gago M., Análisis de los trabajos publicados en revistas y congresos nacionales en relación con humedales españoles durante el período 1989-1999. Murcia: VII Simposio de Hidrología. Asociación Española de Hidrólogos, pp. 31-41, 2001.

[3] Ramírez-Juidías E, López-Lineros M, Madueño-Luna, A., Predicción anual de los cambios volumétricos de las Marismas de Doñana mediante el uso de imágenes satélite. Lugo: V Congreso Nacional y II Congreso Ibérico Agroingeniería. Sociedad Española de Agroingeniería, pp. 199-200, 2009.

[4] Juidias ER, Segovia MJ, Luna AM., New method to predict the volumetric changes in the Odiel marshes (Huelva, Spain). Lecture Notes in Engineering and Computer Science: Proceedings of The World Congress on Engineering 2013, U.K., 3-5 July, London, pp. 1335-1339, 2013.

[5] Ramírez-Juidías E, Pozo-Morales L, Galán-Ortiz L., Procedimiento para la obtención de una imagen teledetectada a partir de fotografía. University of Seville, Spain, Patent n ${ }^{\circ}$ P201300573, 14/06/2013.

[6] Castellanos EM, Nieva FJ, Luque CJ, Figueroa ME., Modelo anual de la dinámica sedimentaria en una marisma mareal mediterránea. Cuaternario y Geomorfología, vol. 12, n 3-4, pp. 69-76, 1998.

[7] Ramírez-Juidías E, Galán-Ortiz L., Utilización de la detección remota como herramienta básica para la restauración de humedales degradados. Almonte, Huelva: V Congreso Nacional de la AEIP. Asociación Española de Ingeniería del Paisaje, pp. 35-39, 2007.

[8] Henry JB, Matgen P, Tholey N, Pfister L, Hoffmann L, De Fraipont P., Vers une intégration des techniques spatiales pour la gestion des inondations. Bulletin de la Société Française de Photogrammétrie et de Télédétection, vol. 172, pp. 99-106, 2003.

[9] Consejería de Medio Ambiente. Medio siglo de cambios en la evolución de usos del suelo en Andalucía 1956-2007. Sevilla: Junta de Andalucía. 2011.

[10] Lowry, R. VassarStats, website for statistical computation. Available: http://vassarstats.net/anovalu.html. Accessed on [2013-20-11].

[11] Castillo JM, Rubio-Casal AE, Luque CJ, Nieva FJ, Figueroa ME., Wetland loss by erosion in Odiel marshes (SW Spain). Journal of Coastal Research. vol. 36, pp. 134-138, 2002 